\title{
Obituary
}

Editor: Henry R. Rollin

Ornulv Ødegard, formerly Medical Superintendent, Gaustad Psychiatric Hospital, Oslo, Norway.

Professor Ørnulv Ødegård died on 2 February 1987 at the age of almost 85 years. He was a leading figure in international psychiatric epidemiology, genetics and social psychiatry.

Ødegård graduated from the University of Oslo in 1925. Hespent important research years in Baltimore with Adolph Meyer (1927-30), by whom he was strongly influenced, and as a result he wrote his opus in 1932, Emigration and Insanity, now considered a classic.

After his return to Norway, he worked in the Norwegian Health Ministry till his appointment at Gaustad Hospital, where he was the head and director from 1939 till his retirement in 1972. In 1950 he was appointed Professor of Psychiatry at the University of Oslo. Ødegard created in 1936 the first national register of psychoses in the world. In the Norwegian register all cases of hospital-admitted patients in Norway from 1916 until today are on file. He and his coworkers opened the way for epidemiological research which inspired similar methods throughout the world. In genetics he found strong evidences for a polygenetic inheritance in many psychiatric disorders. He also had a strong interest in psychiatric classification, and was an important member of WHO's working group on this topic.

He was equally concerned with all factors leading to psychiatric disorders, whether of genetic, biological, organic, social or psychological origin. He strongly advocated the Scandinavian concept of reactive psychoses. To his last compilatory study (in Psychiatrie der Gegenwart 1975) he gave a title which comprehensively covered most of his main interests:

"Social and ecological factors in the etiology, outcome, treatment and prevention of mental disorders."

He was an eminent lecturer, beloved by his students, and a prominent administrator. Beside his professional interests he had outstanding knowledge of botany and literature.

Professor Ødegård was a member and honorary member of several national and international associations and organisations. He was elected an honorary fellow of the College in 1977. As a person he was a modest and friendly man, who lived long enough to see the fruits of what he had seeded. Norwegian and international psychiatry has suffered a great loss by his passing away.

NR

\section{John Alexander Fraser Roberts, Geneticist, Paediatric Research Unit, Guy's Hospital Medical School, London SE1.}

FR died on 15 January 1987 at the age of 87 . He had joined the Royal Medico-Psychological Association in 1938, and this, combined with the fact that "he had been a consultant for twelve years and shown evidence of further merit" qualified him for election as a Foundation Fellow when the Royal College of Psychiatrists was established in 1971.

John's Introduction to Medical Genetics was my Bible in the 1950s, but I must confess that at that time I was more taken with his vivid Welsh imagination than with the intricacies of multifactorial inheritance. His description of how the boy George Huntington saw his first choreics when driving through a wooded lane in Long Island while accompanying his father on professional rounds is memorable. They suddently "came upon two women, mother and daughter, both tall, thin, almost cadaverous; both bowing, twisting, grimacing, so that he stared in wonderment, almost in fear. The memory was as vivid more than $\mathbf{5 0}$ years later, long after he had translated into fact the youthful resolve, born that day, to make chorea the subject of his first contribution to medical science: a resolve which led him into many a home where the bearers of the gene waited with stern Calvinistic stoicism for the dreadful fate which Providence had meted out to them".

John's career was an interesting mixture. After school in Denbigh he was just old enough to serve in World War I, joining the Royal Welch Fusiliers. He then went to Cambridge, reading biology at Gonville and Caius College. Next he obtained a research appointment in the Institute of Animal Genetics at Edinburgh under F. A. E. Crewe and there from 1922 to 1928 he studied the genetics of coat colour and pattern in sheep, and carried on with this when he was appointed biologist to the Wool Industry's Research Association in Leeds. Based on this work he obtained his Edinburgh DSc.

Gradually his interest switched to human genetics, particularly the inheritance of mental disease, and in 1933 he joined the Burden Mental Research Trust Department at Stoke Park, Bristol, and later became its Director. There he carried out many surveys on the genetics of mental ability but he increasingly felt the need of medical training and at the age of 36 graduated MB, ChB at Edinburgh.

Then came the second world war in which he served as a surgeon commander and consultant in medical statistics to the Royal Navy, and after it ended he went as lecturer in genetics to the London School of Hygiene and Tropical Medicine. It was then that he came to the forefront, with Aird, in blood groups and disease, cancer of the stomach and blood group $A$ and peptic ulcer and blood group 0 being among his "firsts". It was at this time that I got to know him well and he guided our faltering footsteps into the problems of duodenal ulcer and blood group 0; we learnt so much from the protagonists (FR and his colleagues) and the critics-Lionel Penrose particularly, who disbelieved the association.

FR was elected to the Royal Society in 1963 for his ABO work and for his substantial contributions to knowledge on geographical variations in the frequencies of the blood group genes. 